\title{
PROFIL KOMPETENSI DUNIA KERJA BIDANG PERBAIKAN BODI OTOMOTIF DAN TINGKAT RELEVANSINYA DENGAN DUNIA PENDIDIKAN
}

\author{
Afri Yudantoko \\ Program Studi Pendidikan Teknologi dan Kejuruan PPs UNY \\ afriyudantoko@gmail.com \\ Zainal Arifin \\ Fakultas Teknik Universitas Negeri Yogyakarta \\ za.otomotif@gmail.com \\ Abstrak
}

Penelitian ini bertujuan untuk mendapatkan informasi tentang: (1) profil kompetensi DU/DI bidang perbaikan bodi otomotif, (2) profil kompetensi TPBO pada SMK di Kabupaten Bantul, dan (3) tingkat relevansi antara profil kompetensi DU/DI bidang perbaikan bodi otomotif dengan profil kompetensi TPBO pada SMK di Kabupaten Bantul. Penelitian ini merupakan penelitian deskriptif komparatif dengan pendekatan penelitian kuantitatif yang didukung dengan data kualitatif sebagai bahan memperkuat data dalam bab pembahasan dengan metode penelitian survei. Penelitian ini melibatkan 42 responden dari DU/DI bidang perbaikan bodi otomotif, 7 guru, dan 29 siswa SMK TPBO di Kabupaten Bantul. Hasil penelitian menunjukkan: (1) terdapat 147 butir kompetensi dalam profil kompetensi DU/DI bidang perbaikan bodi otomotif, (2) terdapat 85 butir kompetensi yang terdapat dalam dokumen KTSP SMK TPBO di Kabupaten Bantul dan 103 butir kompetensi yang menjadi profil kompetensi kerja yang diimplementasikan dalam pembelajaran pada SMK TPBO di Kabupaten Bantul, dan (3) tingkat relevansi antara profil kompetensi DU/DI bidang perbaikan bodi otomotif dengan profil kompetensi dokumen KTSP SMK TPBO di Kabupaten Bantul menunjukkan angka 27,211\% (tidak relevan). Sedangkan tingkat relevansi dengan profil kompetensi kerja yang diimplementasikan dalam pembelajaran pada SMK TPBO di Kabupaten Bantul menunjukkan angka 70,068\% (relevan).

Kata kunci: profil kompetensi dunia kerja bidang perbaikan bodi otomotif, profil kompetensi TPBO pada SMK, Relevansi.

\section{THE COMPETENCY PROFILE OF THE WORLD OF WORK OF AUTOMOTIVE BODY REPAIR SECTOR AND ITS LEVEL OF RELEVANCE TO THE EDUCATION WORLD}

\begin{abstract}
This study aimed to get information about: (1) the competency profile of Business World/ Industrial World (BW/IW) of automotive body repair sector, (2) the competency profile of TPBO SMK in Bantul, and (3) the level of relevance between the competency profile of BW/IW automotive body repair sector and the competency profile of TPBO SMK in Bantul. This research was descriptive comparative using the quantitative research approach accompanied by qualitative data as supporting data in the discussion chapter with the survey method. This research involved 42 respondents from $B W / I W$ automotive body repair sector, 7 teachers, and 29 students from TPBO SMK in Bantul. The results showed: (1) there were 147 items of competency in the competency profile of BW/IW automotive body repair sector, (2) there were 85 items of competency contained in the curriculum of TPBO SMK in Bantul and 103 items of competency in the work competency profile implemented in teaching processes at TPBO SMK in Bantul, and (3) the level of relevance between the competency profile of BW/IW automotive body repair sector and the competency profile of the curriculum of TPBO SMK in Bantul was $27.211 \%$ (irrelevant). The level of relevance with the work competency profile implemented in teaching processes at TPBO SMK in Bantul was $70.068 \%$ (relevant).
\end{abstract}

Keywords: competency profile of world of work of automotive body repair sector, competency profile of TPBO SMK, and relevance 


\section{PENDAHULUAN}

ASEAN Economic Community (AEC) menjadi sebuah tantangan bagi negara-negara yang tergabung dalam Association of South East Asian Nations (ASEAN). Salah satu karakteristik AEC adalah adanya pasar tunggal dan berbasis produksi (ASEAN, 2008, p.6). Karakteristik pasar tunggal dan berbasis produksi dalam AEC didukung oleh lima elemen, salah satunya adalah aliran bebas tenaga kerja terdidik dan aliran bebas modal (Wangke, 2014, p.6). Hal tersebut menegaskan bahwa Sumber Daya Manusia (SDM) yang berkualitas memegang peranan penting.

Menurut laporan United Nations Development Programme (2014, p.161), SDM Indonesia menempati urutan ke-108 dari 187 negara di dunia. Laporan tersebut memberikan informasi bahwa kualitas SDM Indonesia masih tergolong rendah. Salah satu cara meningkatkan kualitas SDM dapat dilakukan melalui pendidikan yang berkualitas. Pendidikan yang berkualitas akan menghasilkan SDM yang berkualitas. Isjoni (2008, p.3) menyatakan bahwa "pendidikan identik dengan output SDM, dan SDM yang berkualitas hanya dapat terbentuk bilamana terdapat proses pendidikan yang berkualitas".

Salah satu jenis pendidikan pada jenjang pendidikan menengah di Indonesia adalah pendidikan kejuruan. Sudira (2012, p.13) mengatakan bahwa "Pendidikan kejuruan merupakan pendidikan menengah yang mempersiapkan peserta didik terutama untuk bekerja dalam bidang tertentu". Dari pernyataan tersebut, secara tidak langsung dapat dikatakan bahwa pendidikan kejuruan bertujuan menghasilkan tenaga kerja terdidik. Hal ini menegaskan bahwa pendidikan kejuruan memegang peranan yang sangat penting dalam rangka menghadapi AEC.

Lembaga pendidikan kejuruan di Indonesia dikenal dengan istilah Sekolah Menengah Kejuruan (SMK). Sesuai dengan data pokok SMK yang dirilis oleh Direktorat Pembinaan SMK (DitPSMK), di Indonesia terdapat 11.738 SMK yang telah terdata (http:// datapokok.ditpsmk.net/ diakses pada tanggal 19 Mei 2015). Dari sejumlah tersebut, 4.177 SMK atau 35,59\% merupakan SMK yang memiliki program studi teknik otomotif. Selain itu, 62,25\% yaitu 902.495 dari 1.449 .796 siswa SMK bidang keahlian teknologi dan rekayasa merupakan siswa yang belajar menekuni program studi keahlian teknik otomotif (http://datapokok.ditpsmk.net/ diakses pada tanggal 19 Mei 2015). Data tersebut memberikan informasi bahwa program studi teknik otomotif merupakan program studi yang paling banyak diselenggarakan di Indonesia.

Hasil Survei Angkatan Kerja Nasional (Sakernas) Badan Pusat Statistik mencatat bahwa pada tahun 2014, angka jumlah pengangguran terbuka mencapai 7.244.905 orang. Dari sejumlah tersebut, 1.332 .521 orang (18\%) merupakan pengangguran berpendidikan terakhir SMK (http://bps.go.id/ diakses pada tanggal 19 Mei 2015). Di Daerah Istimewa Yogyakarta, Kementerian Ketenagakerjaan Republik Indonesia mencatat bahwa dari seluruh jumlah pengangguran terbuka sebesar 67.418 orang, terdapat sekitar kurang lebih $2 \%$ atau 1.335 orang pengangguran yang memiliki keterampilan di bidang otomotif (http://pusdatinaker.balitfo.depnakertrans.go.i d/ diakses pada tanggal 19 Mei 2015). Hal tersebut memberikan informasi bahwa penyelenggaraan pendidikan SMK di DI. Yogykarta khususnya program studi teknik otomotif masih belum efektif.

Program studi teknik otomotif terdiri dari lima kompetensi keahlian yaitu: (1) teknik kendaraan ringan, (2) teknik sepeda motor, (3) teknik perbaikan bodi otomotif, (4) teknik alat berat, dan (5) teknik autotronik. Kompetensi keahlian Teknik Perbaikan Bodi Otomotif (TPBO) merupakan kompetensi keahlian yang sedang berkembang dan memiliki harapan serta peluang masa depan yang baik. Hal ini karena adanya fenomena saat ini mengenai pertumbuhan kendaraan bermotor beserta industrinya yang cukup pesat, tidak bertambah-lebarnya infrastruktur jalan, dan maraknya modifikasi aksesoris kendaraan.

Di DI. Yogyakarta terdapat 3 (tiga) SMK yang menyelenggarakan kompetensi keahlian TPBO. Tabel 1 berikut ini akan menyajikan mengenai ketiga SMK tersebut.

Tabel 1. SMK TPBO di Provinsi DI. Yogyakarta.

\begin{tabular}{cll}
\hline No & Nama SMK & Kabupaten \\
\hline 1 & SMK N 1 Sanden & Bantul \\
2 & SMK Teknologi Bantul & Bantul \\
3 & SMK N 2 Depok & Sleman \\
\hline \multicolumn{2}{l}{ Sumber: diolah dari http://datapokok.ditpsmk.net/ }
\end{tabular}


Hasil observasi pra-survei yang telah dilakukan, didapatkan data bahwa dua SMK TPBO di wilayah Kabupaten Bantul yaitu SMK N 1 Sanden dan SMK Teknologi Bantul merupakan SMK yang masih tergolong baru dan masih dalam proses pengembangan. Kedua SMK tersebut tercatat belum menghasilkan lulusan siswa TPBO. Tahun ini merupakan tahun ketiga dalam penyelenggaraan kompetensi keahlian TPBO di dua SMK tersebut. Selain itu, kedua SMK tersebut belum terakreditasi dan belum menerapkan suatu standar penjaminan mutu dalam penyelenggaraan program pendidikannya.

SMK TPBO di Kabupaten Bantul, dalam penyelenggaraan pendidikannya menerapkan kurikulum KTSP. Dalam hal sarana prasarana praktik di dua SMK TPBO tersebut masih kurang memadai. Hal ini sesuai dengan persepsi ketua jurusan TPBO yang memperkirakan persentase kurang lebih hanya 50\% dari segi keberadaan dan keberfungsian sarana dan prasarana praktik ketika ditinjau dari Standar Kompetensi Kerja Nasional Indonesia (SKKNI). Selain itu, dalam hal kerja sama dengan Dunia Usaha/ Dunia Industri (DU/DI), kedua SMK TPBO di Kabupaten Bantul tersebut belum memiliki jalinan kerja sama yang baik dengan pihak DU/DI. Hal ini berkebalikan dengan teori pendidikan kejuruan yang efisien jika dalam penyelenggaraannya berdasarkan situasi dan kebutuhan DU/DI (Prosser \& Quigley, 1950, pp.234-235).

Data hasil analisis instrumen angket yang telah disebarkan pada sejumlah guru di 3 SMK TPBO di DI. Yogyakarta, menyatakan bahwa persentase dalam hal pengalaman guru terjun dalam DU/DI bidang TPBO rata-rata $60 \%$ dan persentase guru yang mendapatkan pengalaman dari berbagai pelatihan terkait bidang TPBO rata-rata $72 \%$. Selain itu, guru memiliki persepsi relevansi materi yang diajarkan di SMK dengan kebutuhan DU/DI baru mencapai $80 \%$. Hal ini perlu mendapatkan perhatian yang lebih dalam meningkatkan efisiensi penyelenggaraan SMK.

Hasil survei di 9 (sembilan) DU/DI yang menjadi tempat Praktik Industri (PI) siswa SMK TPBO di Kabupaten Bantul menyatakan bahwa rata-rata persepsi DU/DI dalam hal merasa terbantu dengan adanya PI siswa SMK TPBO tersebut hanya 36\%. Selain itu, DU/DI memiliki persepsi bahwa kesesuaian kompetensi yang dimiliki siswa kedua
SMK TPBO tersebut terhadap kebutuhannya (DU/DI) rata-rata hanya 39\%. Rata-rata 97\% DU/DI sangat setuju dalam hal pernyataan perlu adanya pembenahan dan pengembangan SMK TPBO tersebut terutama dalam hal pembelajaran kompetensi.

Hasil survei lainnya menyatakan bahwa pegawai DU/DI yang lulusan SMK bidang otomotif hanya $17 \%$ sedangkan sisanya merupakan lulusan SD hingga SMA atau bahkan tidak memiliki ijazah pendidikan. Data tersebut menimbulkan pertanyaan, apakah terdapat relevansi kompetensi yang kurang baik antara kompetensi yang diajarkan di SMK TPBO dengan kompetensi yang dibutuhkan di DU/DI sehingga menyebabkan munculnya fenomena-fenomena tersebut.

SMK TPBO sebagai salah satu bagian dari pendidikan kejuruan harus mampu mempersiapkan peserta didik siap terjun dalam dunia kerja. Oleh karena itu, hubungan dan relevansi SMK-DU/DI menjadi suatu hal yang sangat penting. Peningkatan kualitas pendidikan kejuruan dilakukan dengan meningkatkan kualitas dan relevansi terhadap kondisi tempat kerja. Hal ini sesuai dengan pernyataan: “...improves the VET sector's capacity to increase access to vocational education and training of quality and relevance to the workplace" (Palmieri, 2004, pp.95-96). Ali (2009, p.300) menyatakan bahwa makna relevansi dalam dunia pendidikan adalah "...kesesuaian antara proses dan materi yang diberikan dalam pendidikan dengan kebutuhan pasar".

Kajian penelitian mengenai profil kompetensi DU/DI bidang perbaikan bodi otomotif dan relevansinya terhadap kurikulum SMK TPBO hingga saat ini masih belum ada. Beberapa penelitian mengenai relevansi banyak ditujukan pada kompetensi keahlian teknik kendaraan ringan. Beberapa penelitian tersebut d iantaranya: Simamora (2009) dengan judul "Relevansi Kompetensi Siswa SMK Negeri Program Keahlian Teknik Mekanik Otomotif dengan Kebutuhan Dunia Usaha/Dunia Industri Otomotif di Kota Medan", Priyatama \& Sukardi (2013) dengan judul "Profil Kompetensi Siswa SMK Kompetensi Keahlian Teknik Kendaraan Ringan di Kota Pekalongan", dan Jatmoko (2013) dengan judul "Relevansi Kurikulum SMK Kompetensi Keahlian Teknik Kendaraan Ringan terhadap Kebutuhan Dunia Industri di Kabupaten Sleman". 
Berdasarkan data permasalahan SMK TPBO di Kabupaten Bantul dan data persepsi DU/DI yang telah diuraikan, penelitian ini bertujuan untuk mengkaji profil kompetensi DU/DI bidang perbaikan bodi otomotif dan relevansinya terhadap profil kompetensi SMK TPBO.

\section{METODE PENELITIAN}

Penelitian ini merupakan penelitian deskriptif komparatif dengan pendekatan penelitian kuantitatif yang didukung dengan data kualitatif sebagai bahan memperkuat data dalam bab pembahasan dengan metode penelitian survei.

Penelitian ini dilaksanakan pada bulan November hingga Desember 2015 di 2 (dua) SMK TPBO di Kabupaten Bantul dan di 14 (empat belas) DU/DI bidang TPBO di DI. Yogyakarta. Penentuan sampel dalam penelitian ini menggunakan teknik purposive sampling dan sampling jenuh. Teknik purposive sampling digunakan dalam menentukan SMK dan DU/DI sedangkan teknik sampling jenuh digunakan dalam menentukan ukuran sampel dari setiap kelompok (kepala bengkel, kepala mekanik, guru, dan siswa).

Tabel 2. Responden dari DU/DI Bidang TPBO

\begin{tabular}{lcc}
\hline \multirow{2}{*}{ Nama DU/DI } & \multicolumn{2}{c}{ Responden } \\
\cline { 2 - 3 } & $\begin{array}{c}\text { Kepala } \\
\text { Bengkel }\end{array}$ & $\begin{array}{c}\text { Kepala } \\
\text { Mekanik }\end{array}$ \\
\hline Nasmoco Bantul & 1 & 7 \\
Honda Anugerah & 1 & 3 \\
Daihatsu & 1 & 1 \\
Sumber Auto & 1 & 2 \\
Maestro & 1 & 2 \\
Jogja Speed Concat & 1 & 1 \\
DjogjaDab & 1 & 1 \\
M-1 & 1 & 1 \\
Grand Star & 1 & 2 \\
Auto-1 & 1 & 2 \\
Monaco & 1 & 2 \\
Atlanta Jombor & 1 & 1 \\
New General & 1 & 1 \\
Kupu-kupu Malam & 1 & 2 \\
\hline \multicolumn{1}{c}{ Jumlah } & 14 & 28 \\
\hline
\end{tabular}

(Sumber: diolah dari observasi pra-survei)
Tabel 3. Responden dari SMK TPBO

\begin{tabular}{lcc}
\hline \multirow{2}{*}{ Nama SMK } & \multicolumn{2}{c}{ Responden } \\
\cline { 2 - 3 } & Guru & Siswa \\
\hline SMK Negeri 1 Sanden & 5 & 12 \\
SMK Teknologi Bantul & 2 & 17 \\
Jumlah & 7 & 29 \\
\hline
\end{tabular}

(Sumber: diolah dari observasi pra-survei)

Variabel yang terdapat dalam penelitian ini adalah profil kompetensi DU/DI bidang perbaikan bodi otomotif, profil kompetensi pada SMK TPBO di Kabupaten Bantul, dan tingkat relevansi antara kedua profil kompetensi tersebut.

Teknik pengumpulan data dalam penelitian ini menggunakan teknik angket dan dokumentasi. Teknik angket digunakan untuk menggali persepsi kepala bengkel dan kepala mekanik dalam hal kompetensi DU/DI bidang perbaikan bodi otomotif. Selain itu, teknik ini juga digunakan untuk mengumpulkan data mengenai persepsi guru dan siswa dalam hal profil kompetensi kerja DU/DI yang diimplementasikan dalam pembelajaran pada SMK TPBO di Kabupaten Bantul. Teknik dokumentasi digunakan untuk menggali datadata kompetensi yang ada di dalam dokumen kurikulum KTSP SMK TPBO di Kabupaten Bantul.

Berdasarkan teknik pengambilan data yang telah diuraikan tersebut, maka instrumen pengumpulan data dalam penelitian ini adalah angket yaitu lembar angket kuesioner persepsi kepala bengkel, kepala mekanik, guru, dan siswa terhadap kompetensi bidang perbaikan bodi otomotif.

Teknik pengumpulan data kualitatif sebagai data pendukung pembahasan dalam penelitian ini menggunakan teknik wawancara terstruktur dan observasi. Wawancara terstruktur dilakukan dengan kepala bengkel DU/DI TPBO dan kepala jurusan TPBO SMK untuk menggali kompetensi bidang perbaikan bodi otomotif yang belum terdapat dalam angket. Teknik observasi digunakan untuk observasi sarana pendukung SMK TPBO di Kabupaten Bantul dalam mengimplementasi pembelajaran kompetensi kepada peserta didiknya.

Teknik analisis data dalam penelitian ini menggunakan teknik analisis data deskriptif kuantitatif. Teknik analisis data dalam 
penelitian ini dibedakan menjadi 3 (tiga) yaitu teknik analisis data pada perumusan profil kompetensi DU/DI bidang perbaikan bodi otomotif, teknik analisis data pada perumusan profil kompetensi SMK TPBO di Kabupaten Bantul, dan teknik analisis yang digunakan dalam menentukan tingkat relevansi diantara kedua profil kompetensi tersebut.

Teknik analisis data pada perumusan profil kompetensi DU/DI bidang perbaikan bodi otomotif menggunakan teknik analisis statistik deskriptif. Glass \& Hopkins (1996, p.2) menyatakan bahwa "Descriptive statistics involves tabulating, depicting, and describing sets of data". Dalam analisis statistik deskriptif ini akan disajikan data melalui tabel distribusi frekuensi dan histogram, ukuran-ukuran deskriptif statistik (ukuran tendensi sentral, ukuran simpangan, dan ukuran kemiringan serta kurtosis), persentase skor dari setiap butir instrumen, dan penentuan butir tersebut diterima atau ditolak dalam rangka memperoleh profil kompetensi DU/DI bidang perbaikan bodi otomotif.

Setelah diperoleh persentase skor tiap butir instrumen, maka langkah selanjutnya adalah menentukan butir kompetensi tersebut diterima atau ditolak. Penentuan tersebut didasarkan pada analisis hasil persentase setiap butir dalam kaidah kategorisasi. Suatu butir kompetensi akan diterima apabila persentase yag didapatkan masuk dalam kategori "tinggi". Berikut ini analisis kategorisasi (3 kategori) yang digunakan menurut Azwar (2015).

Tabel 4. Kaidah Interpretasi Persentase ke dalam 3 Kategori.

\begin{tabular}{cccc}
\hline & Interval & Kategori \\
\hline$\overline{M_{i}}+1,0 S D_{i}$ & $\leq x \leq$ & $100 \%$ & Tinggi \\
\hline$\overline{M_{i}}-1,0 S D_{i}$ & $\leq x<$ & $\overline{M_{i}}+1,0 S D_{i}$ & Sedang \\
\hline $0 \%$ & $\leq x<$ & $M_{i}^{-}-1,0 S D_{i}$ & Rendah \\
\hline
\end{tabular}

Keterangan :

$M_{i} \quad$ : Rata-rata ideal $=0,5 \mathrm{x}$ (persentase tertinggi + skor terendah)

$S D_{i} \quad$ : Simpangan baku ideal $=1 / 6 \times$ (persentase tertinggi - persentase terendah)

$x \quad$ : Skor yang dicapai

Persentase Tertinggi : jawaban alternatif tertinggi $(4)=100 \%$

Persentase Terendah : jawaban alternatif terendah $(0)=0 \%$
Dari Tabel 4 dan keterangan tersebut, maka dapat disimpulkan bahwa nilai rata-rata ideal sebesar $50 \%$ dan nilai simpangan baku ideal sebesar $16,67 \%$. Dari kedua nilai tersebut, Tabel 5 berikut ini akan menjelaskan mengenai pedoman konversi persentase terhadap 3 kategorisasi.

Tabel 5. Pedoman Konversi Persentase Terhadap 3 Kategorisasi.

\begin{tabular}{cccc}
\hline \multicolumn{3}{c}{ Interval } & Kategori \\
\hline $66,67 \%$ & $\leq x \leq 100 \%$ & Tinggi \\
$33,33 \%$ & $\leq x<$ & $66,67 \%$ & Sedang \\
$0 \%$ & $\leq x<$ & $33,33 \%$ & Rendah \\
\hline
\end{tabular}

Teknik analisis data pada perumusan profil kompetensi SMK TPBO di Kabupaten Bantul dibedakan menjadi dua hal yaitu teknik analisis data pada dokumen KTSP SMK TPBO dan teknik analisis data pada profil kompetensi yang diimplementasikan dalam pembelajaran pada SMK TPBO di Kabupaten Bantul. Teknik analisis pada dokumen KTSP SMK TPBO dilakukan dengan mengambil data kompetensi dari dokumen KTSP kemudian mengelompokkan kompetensi tersebut sesuai dengan bidang pekerjaan yang ada dalam bidang perbaikan bodi otomotif.

Teknik analisis data pada profil kompetensi yang diimplementasikan dalam pembelajaran pada SMK TPBO di Kabupaten Bantul sama dengan analisis dalam perumusan profil kompetensi DU/DI bidang perbaikan bodi otomotif menggunakan teknik analisis statistik deskriptif. Suatu butir kompetensi dikatakan diterima dalam analisis kuantitatif apabila memperoleh persentase $\geq 66,67 \%$. Dalam hal ini, persentase diperoleh dari ratarata nilai persentase persepsi guru dan persepsi siswa terhadap kompetensi yang diimplementasikan. Tabel 6 berikut merupakan pedoman dari analisis data kuantitatif tersebut.

Tabel 6. Tabel Pedoman Analisis Implementasi Kompetensi SMK TPBO

\begin{tabular}{lcccc}
\hline \multirow{2}{*}{ Kompetensi } & \multicolumn{2}{c}{ Kuesioner } & Rata-rata & Kesimpulan \\
\cline { 2 - 4 } & Guru & Siswa & & \\
\hline Butir & $\%$ & $\%$ & $\%$ & $\begin{array}{c}\text { Diajarkan } \\
\text { atau Tidak }\end{array}$ \\
\hline
\end{tabular}


Teknik analisis yang digunakan dalam menentukan tingkat relevansi antara profil kompetensi DU/DI bidang perbaikan bodi otomotif dengan profil kompetensi yang ada dalam dokumen KTSP dan profil kompetensi yang diimplementasikan dalam pembelajaran pada SMK TPBO di Kabupaten Bantul dilakukan dalam dua tahap. Tahap pertama dilakukan dengan klasifikasi peta kompetensi menjadi 3 (tiga) bagian sebagai berikut: (1) kompetensi yang terdapat pada profil kompetensi TPBO yang menjadi kebutuhan DU/DI dan terdapat pada profil kompetensi pada SMK TPBO, (2) kompetensi yang terdapat pada profil kompetensi TPBO yang menjadi kebutuhan DU/DI namun tidak terdapat pada profil kompetensi pada SMK TPBO, dan (3) kompetensi yang tidak terdapat pada profil kompetensi TPBO yang menjadi kebutuhan DU/DI namun terdapat pada profil kompetensi pada SMK TPBO.

Tahap kedua setelah tahap pertama tersebut selesai dilakukan adalah menghitung tingkat relevansi yang diungkapkan melalui persentase. Persentase tingkat relevansi dapat dihitung dari jumlah butir kompetensi yang terdapat pada SMK TPBO dibandingkan dengan jumlah butir kompetensi DU/DI bidang perbaikan bodi otomotif. Nilai persentase tingkat relevansi tersebut diintepretasikan menjadi data kualitatif dengan kaidah distribusi normal (Wagiran, 2013) pada Tabel 7.

Tabel 7. Kaidah Interpretasi Kurva Distribusi Normal

\begin{tabular}{lll}
\hline & Interval & \multicolumn{1}{c}{ Kategori } \\
\hline$\overline{M_{i}^{-}}+1,8 S D_{i}$ & $<x \leq \overline{M_{i}}+3 S D_{i}$ & Sangat Relevan \\
$M_{i}^{-}+0,6 S D_{i}$ & $<x \leq \overline{M_{i}}+1,8 S D_{i}$ & Relevan \\
$\overline{M_{i}^{-}}-0,6 S D_{i}$ & $<x \leq \overline{M_{i}^{-}}+0,6 S D_{i}$ & Kurang Relevan \\
$\overline{M_{i}}-1,8 S D_{i}$ & $<x \leq \overline{M_{i}^{-}}-0,6 S D_{i}$ & Tidak Relevan \\
$M_{i}^{-}-3 S D_{i}$ & $\leq x \leq \overline{M_{i}}-1,8 S D_{i}$ & Sangat Tidak \\
& & Relevan \\
\hline
\end{tabular}

Keterangan :

$M_{i} \quad$ : Rata-rata ideal $=0,5 \mathrm{x}$ (persentase tertinggi + skor terendah)

$S D_{i} \quad:$ Simpangan baku ideal $=1 / 6 \times$ (persentase tertinggi - persentase terendah)

$x \quad$ : Skor yang dicapai

Persentase Tertinggi : jawaban alternatif tertinggi

$$
(4)=100 \%
$$

Persentase Terendah : jawaban alternatif terendah

$$
\text { (0) }=0 \%
$$

Dari Tabel 7 dan keterangan tersebut, maka dapat disimpulkan bahwa nilai rata-rata ideal sebesar $50 \%$ dan nilai simpangan baku ideal sebesar $16,67 \%$. Dari kedua nilai tersebut, Tabel 8 berikut ini akan menjelaskan mengenai pedoman konversi persentase terhadap tingkat relevansi.

Tabel 8. Pedoman Konversi Persentase terhadap Tingkat Relevansi.

\begin{tabular}{ll}
\hline \multicolumn{1}{c}{ Interval } & \multicolumn{1}{c}{ Kategori } \\
\hline $80 \%<x \leq 100 \%$ & Sangat Relevan \\
\hline $60 \%<x \leq 80 \%$ & Relevan \\
\hline $40 \%<x \leq 60 \%$ & Kurang Relevan \\
\hline $20 \%<x \leq 40 \%$ & Tidak Relevan \\
\hline $0 \% \leq x \leq 20 \%$ & Sangat Tidak Relevan \\
\hline
\end{tabular}

\section{HASIL PENELITIAN DAN PEMBAHASAN}

\section{Hasil Penelitian}

Hasil pada penelitian ini secara umum terbagi menjadi 3 (tiga) hal yaitu profil kompetensi DU/DI bidang perbaikan bodi otomotif, profil kompetensi pada SMK TPBO di Kabupaten Bantul, dan tingkat relevansi antara kedua profil kompetensi tersebut. Profil kompetensi pada SMK TPBO di Kabupaten Bantul terbagi menjadi 2 (dua) yaitu profil kompetensi pada dokumen dan profil kompetensi yang diimplementasikan dalam pembelajaran. Oleh karena itu, tingkat relevansi juga terbagi menjadi 2 (dua) yaitu tingkat relevansi antara profil kompetensi DU/DI bidang perbaikan bodi otomotif dengan profil kompetensi pada dokumen KTSP SMK TPBO di Kabupaten Bantul dan tingkat relevansi antara profil kompetensi DU/DI bidang perbaikan bodi otomotif dengan profil kompetensi yang diimplementasikan dalam pembelajaran pada SMK TPBO di Kabupaten Bantul. Dalam deskripsi hasil penelitian ini akan disajikan dalam 5 hal sebagai berikut.

\section{Profil Kompetensi DU/DI Bidang Perbaikan Bodi Otomotif}

Profil kompetensi DU/DI bidang perbaikan bodi otomotif terbagi menjadi 8 (delapan) sub-kompetensi sesuai dengan bidang pekerjaannya. Tabel 9 berikut ini merupakan tabel profil kompetensi DU/DI bidang perbaikan bodi otomotif. 
Tabel 9. Profil Kompetensi DU/DI Bidang Perbaikan Bodi Otomotif

\begin{tabular}{|c|c|c|}
\hline \multirow{2}{*}{$\frac{\text { No }}{1}$} & Bidang Kompetensi & Butir Kompetensi \\
\hline & $\begin{array}{l}\text { Profil Kompetensi } \\
\text { Intrapersonal } \\
\text { (Intrapersonal } \\
\text { Competencies) }\end{array}$ & $\begin{array}{l}\text { Memiliki sikap tanggung jawab yang baik pada setiap pekerjaan yang } \\
\text { dibebankan. } \\
\text { Memiliki sikap mampu menghargai diri sendiri atas pekerjaan yang } \\
\text { dihasilkannya. } \\
\text { Memiliki kemampuan manajemen diri yang baik. } \\
\text { Memiliki sikap integritas atau kejujuran. } \\
\text { Memiliki sikap inisiatif yang baik. } \\
\text { Memiliki sikap dan pemikiran yang produktif. } \\
\text { Memiliki kapasitas untuk berpikir kritis dan analitis. } \\
\text { Memiliki kemauan untuk belajar. } \\
\text { Memiliki komitmen dan dedikasi yang tinggi terhadap pekerjaannya. } \\
\text { Memiliki motivasi yang baik dalam menyelesaikan pekerjaannya. } \\
\text { Memiliki semangat yang tinggi dalam menyelesaikan pekerjaannya. } \\
\text { Memiliki kreativitas yang baik dalam menyelesaikan pekerjaannya. } \\
\text { Memiliki kemampuan untuk mengatasi stress pribadi. } \\
\text { Memiliki kemampuan untuk meringkas langkah-langkah pekerjaan yang lebih } \\
\text { efektif dan efisien. } \\
\text { Memiliki sikap fleksibel terhadap orang lain. } \\
\text { Memiliki sikap kemandirian yang baik. } \\
\text { Memiliki sikap tangguh dalam menghadapi setiap tantangan pekerjaan. } \\
\text { Memiliki kemampuan untuk berargumentasi secara logis. } \\
\text { Memiliki jiwa kewirausahaan. } \\
\text { Memiliki jiwa kewarganegaraan dan nasionalisme. } \\
\text { Memiliki sifat inovatif dalam pekerjaan. } \\
\text { Memiliki kemampuan manajemen waktu yang baik. } \\
\text { Memiliki sikap percaya diri yang baik. } \\
\text { Memiliki kemampuan mengontrol diri secara baik. } \\
\text { Memiliki kemampuan berpikir konseptual dan ilmiah. } \\
\text { Memiliki keberanian diri. } \\
\text { Memiliki sikap ketegasan yang baik. }\end{array}$ \\
\hline 2 & $\begin{array}{l}\text { Profil Kompetensi } \\
\text { Interpersonal } \\
\text { (Interpersonal } \\
\text { Competencies) }\end{array}$ & $\begin{array}{l}\text { Memiliki kemampuan menyelesaikan masalah. } \\
\text { Memiliki sikap empati yang baik terhadap orang lain. } \\
\text { Memiliki sikap kepekaan sosial yang baik. } \\
\text { Memiliki sikap etika yang baik dalam bergaul dengan yang lain. } \\
\text { Memiliki kemampuan untuk mudah beradaptasi dengan yang lain. } \\
\text { Memiliki kemampuan manajemen interaksi komunikasi yang baik. } \\
\text { Memiliki kemampuan dalam berbahasa keseharian. } \\
\text { Memiliki kemampuan dalam berbahasa asing. } \\
\text { Memiliki sikap dan karakter diri untuk dapat diandalkan. } \\
\text { Memiliki kemampuan kepemimpinan yang baik. } \\
\text { Memiliki kemampuan berkooperasi dan bekerja sama dalam tim yang baik. } \\
\text { Memiliki kemampuan teknologi informasi. } \\
\text { Memiliki pengaruh terhadap yang lain. } \\
\text { Memiliki kemampuan pengembangan bagi yang lain. } \\
\text { Memiliki kemampuan menyelesaikan masalah sosial. } \\
\text { Memiliki kemampuan manajemen organisasi. } \\
\text { Memiliki kemampuan manajemen informasi yang baik. } \\
\text { Memiliki tanggung jawab dan kepedulian dalam pengendalian lingkungan. } \\
\text { Memiliki kemampuan berpartisipasi dalam komunitas digital, lokal, nasional, } \\
\text { maupun internasional. }\end{array}$ \\
\hline
\end{tabular}




\begin{tabular}{cl}
\hline No & Bidang Kompetensi \\
\hline 3 & Profil Kompetensi \\
& Umum (General \\
& Competencies)
\end{tabular}

Butir Kompetensi

Memiliki pengetahuan dan mampu melaksanakan prosedur pemeliharaan/servis komponen.

Memiliki pengetahuan dan mampu mengindentifikasi dan menggunakan pelumas/cairan pembersih yang benar.

Memiliki pengetahuan dan mampu melaksanakan pemilihan, penggunaan, dan pemeliharaan peralatan, perlengkapan, dan area di tempat kerja.

Memiliki pengetahuan dan mampu menggunakan segala sumber daya secara tepat di tempat kerja.

Memiliki pengetahuan dan mampu melaksanakan prosedur pemasangan, pengujian, dan pemeliharaan sistem hidrolik.

Memiliki pengetahuan dan mampu melaksanakan prosedur pemeliharaan dan perbaikan kompresor udara dan komponen-komponennya.

Memiliki pengetahuan dan mampu melaksanakan prosedur menggambar, membaca, dan memahami gambar teknik.

Memiliki pengetahuan dan mampu melaksanakan prosedur pemilihan, penggunaan, dan pemeliharaan alat ukur dalam mengukur berbagai dimensi dan variabel.

Memiliki pengetahuan dan mampu melaksanakan prosedur pengesetan, pengoperasian, pengontrolan, dan perawatan mesin.

Memiliki pengetahuan dan mampu melaksanakan pekerjaan pemesinan dalam memotong komponen-komponen.

Memiliki pengetahuan dan mampu melaksanakan operasi penanganan secara manual, mengangkat dan memindahkan material/ komponen/ part.

Memiliki pengetahuan dan mampu melaksanakan prosedur penggunaan alat pengangkat kendaraan.

Memiliki pengetahuan dan mampu mengendarai kendaraan.

Memiliki pengetahuan dan mampu melaksanakan prosedur pemerikasaan keamanan/ kelayakan kendaraan.

Memiliki pengetahuan dan pemahaman mengenai informasi bahan-bahan berbahaya di tempat kerja.

Memiliki kemampuan menjaga keselamatan diri, orang, dan atau benda lainnya ditempat kerja.

Memiliki pengetahuan dan mampu melaksanakan prosedur kerja dalam mengidentifikasi bahaya dan penghindarannya.

Memiliki pengetahuan dan mampu melaksanakan prosedur kerja yang aman sesuai dengan regulasi keselamatan kerja.

Memiliki pengetahuan dan mampu melaksanakan prosedur penanganan sampah di tempat kerja.

Memiliki pengetahuan dan mampu melaksanakan prosedur pencegahan dan penanganan api kebakaran dengan menggunakan alat pemadam kebakaran. Memiliki pengetahuan dan mampu melaksanakan prosedur memelihara, memahami, dan menyampaikan informasi tempat kerja.

Memiliki pengetahuan dan mampu melaksanakan prosedur mempertahankan prestasi di tempat kerja.

4 Profil Kompetensi Perbaikan Panel (Panel Repair Competencies)
Memiliki pengetahuan dan mampu melaksanakan prosedur pekerjaan sebelum perbaikan seperti membersihkan, melepas, menandai dan menyimpan komponen-komponen.

Memiliki pengetahuan dan mampu melaksanakan prosedur pemanasan dan pemotongan termal.

Memiliki pengetahuan dan mampu melaksanakan prosedur pematrian logam.

Memiliki pengetahuan dan mampu melaksanakan prosedur persiapan komponen, peralatan, dan perlengkapan serta pelaksanaan pematrian lunak. Memiliki pengetahuan dan mampu melaksanakan prosedur pengelasan logam. Memiliki pengetahuan dan mampu melaksanakan prosedur pengelasan $\mathrm{CO}_{2}$ (MIG). 


\begin{tabular}{|c|c|c|}
\hline \multirow{23}{*}{\multicolumn{2}{|c|}{ No Bidang Kompetensi }} & Butir Kompetensi \\
\hline & & $\begin{array}{l}\text { Memiliki pengetahuan dan mampu melaksanakan prosedur pengelasan } \mathrm{Ar} \\
\text { (TIG). }\end{array}$ \\
\hline & & $\begin{array}{l}\text { Memiliki pengetahuan dan mampu melaksanakan prosedur pengelasan busur } \\
\text { listrik atau SMAW (Shielded Metal Arc Welder). }\end{array}$ \\
\hline & & Memiliki pengetahuan dan mampu melaksanakan prosedur pengelasan \\
\hline & & STRSW (Squeeze-Type Resistance Spot Welder). \\
\hline & & $\begin{array}{l}\text { Memiliki pengetahuan dan mampu melaksanakan prosedur pengelasan Plasma } \\
\text { Arc Cutter. }\end{array}$ \\
\hline & & $\begin{array}{l}\text { Memiliki pengetahuan dan mampu melakukan prosedur pengelasan gas oxy- } \\
\text { acetylene (karbid). }\end{array}$ \\
\hline & & Memiliki pengetahuan dan mampu melaksanakan prosedur las titik. \\
\hline & & $\begin{array}{l}\text { Memiliki pengetahuan dan mampu melaksanakan prosedur pengelasan bahan } \\
\text { aluminium. }\end{array}$ \\
\hline & & $\begin{array}{l}\text { Memiliki pengetahuan dan mampu melaksanakan prosedur pelepasan dan } \\
\text { penyambungan pada pengelasan panel. }\end{array}$ \\
\hline & & Memiliki pengetahuan dan mampu melaksanakan aplikasi riveting panel. \\
\hline & & $\begin{array}{l}\text { Memiliki pengetahuan dan mampu melaksanakan prosedur pelepasan dan } \\
\text { pemasangan panel bodi, dash panel, panel atap, panel lantai, dan perangkat } \\
\text { tambahan. }\end{array}$ \\
\hline & & $\begin{array}{l}\text { Memiliki pengetahuan dan mampu melaksanakan prosedur penggantian panel } \\
\text { dengan pengelasan. }\end{array}$ \\
\hline & & $\begin{array}{l}\text { Memiliki pengetahuan dan mampu melaksanakan prosedur pembentukan } \\
\text { ulang kerusakan pada panel berbahan besi, aluminium, plastik, maupun } \\
\text { fiberglass. }\end{array}$ \\
\hline & & $\begin{array}{l}\text { Memiliki pengetahuan dan mampu melaksanakan prosedur aplikasi palu dan } \\
\text { dolly dalam pengetokkan panel. }\end{array}$ \\
\hline & & $\begin{array}{l}\text { Memiliki pengetahuan dan mampu melaksanakan prosedur aplikasi } \\
\text { penyusutan atau pengerutan panel (shrinking). }\end{array}$ \\
\hline & & $\begin{array}{l}\text { Memiliki pengetahuan dan mampu melaksanakan prosedur penarikan panel } \\
\text { menggunakan washer welder dan lock chain. }\end{array}$ \\
\hline & & $\begin{array}{l}\text { Memiliki pengetahuan dan mampu melaksanakan prosedur menghilangkan } \\
\text { korosi/kerak (pengamplasan) dan mempersiapkan permukaan bodi untuk } \\
\text { penggunaan cat dasar. }\end{array}$ \\
\hline & & $\begin{array}{l}\text { Memiliki pengetahuan dan mampu melaksanakan prosedur aplikasi cat dasar } \\
\text { (primer) serta mempersiapkan permukaan setelah cat dasar. }\end{array}$ \\
\hline & & $\begin{array}{l}\text { Memiliki pengetahuan dan mampu melaksanakan aplikasi pendempulan pada } \\
\text { panel. }\end{array}$ \\
\hline & & $\begin{array}{l}\text { Memiliki pengetahuan dan mampu melaksanakan prosedur pengujian, } \\
\text { pemasangan, perbaikan dan penggantian komponen sealer kendaraan. }\end{array}$ \\
\hline & & $\begin{array}{l}\text { Memiliki pengetahuan dan mampu melaksanakan prosedur penilaian kualitas } \\
\text { permukaan panel bodi setelah pendempulan atau perbaikan. }\end{array}$ \\
\hline & & $\begin{array}{l}\text { Memiliki pengetahuan dan mampu melaksanakan prosedur pengukuran dan } \\
\text { menilai hasil pengukuran dimensi panel bodi dalam rangka perbaikan. }\end{array}$ \\
\hline \multirow{6}{*}{\multicolumn{2}{|c|}{$\begin{array}{ll}5 & \text { Profil Kompetensi } \\
& \text { Pengecatan Panel } \\
& \text { (Panel Paint } \\
& \text { Competencies) }\end{array}$}} & $\begin{array}{l}\text { Memiliki kemampuan melaksanakan prosedur penggunaan bahan-bahan } \\
\text { pengecatan ulang dengan menggunakan spray gun. }\end{array}$ \\
\hline & & $\begin{array}{l}\text { Memiliki pengetahuan dan mampu melaksanakan prosedur penggunaan bahan- } \\
\text { bahan pengecatan ulang dengan menggunakan kuas. }\end{array}$ \\
\hline & & $\begin{array}{l}\text { Memiliki pengetahuan dan mampu melaksanakan prosedur penggunaan spray } \\
\text { gun dan cat untuk pengecatan panel. }\end{array}$ \\
\hline & & $\begin{array}{l}\text { Memiliki pengetahuan dan mampu melaksanakan prosedur persiapan } \\
\text { komponen, material, bahan, dan peralatan dalam rangka pengecatan kecil (spot } \\
\text { repair). }\end{array}$ \\
\hline & & $\begin{array}{l}\text { Memiliki pengetahuan mengenai berbagai macam tipe dan bahan cat serta } \\
\text { waktu yang diperlukan oleh cat tersebut untuk kering. }\end{array}$ \\
\hline & & ahuan dan mampu melaksanakan prosedur aplikasi surfac \\
\hline
\end{tabular}









\begin{tabular}{|c|c|c|}
\hline No & Bidang Kompetensi & Butir Kompetensi \\
\hline \multirow[t]{12}{*}{7} & \multirow{12}{*}{$\begin{array}{l}\text { Profil Kompetensi } \\
\text { Analisis dan } \\
\text { Manajemen (Analysis } \\
\text { and Management } \\
\text { Competencies) }\end{array}$} & $\begin{array}{l}\text { Memiliki pengetahuan dan mampu melaksanakan prosedur mempersiapkan } \\
\text { kendaraan (kebersihan) sebelum dikembalikan pada pemiliknya. }\end{array}$ \\
\hline & & $\begin{array}{l}\text { Memiliki pengetahuan dan mampu melaksanakan prosedur inspeksi (quality } \\
\text { check) kendaraan baik mulai dari perencanaan hingga pelaksanaan yang } \\
\text { senantiasa mengutamakan keamanan. }\end{array}$ \\
\hline & & $\begin{array}{l}\text { Memiliki pengetahuan dan mampu melaksanakan prosedur diagnosis } \\
\text { kerusakan kendaraan. }\end{array}$ \\
\hline & & $\begin{array}{l}\text { Memiliki pengetahuan dan mampu melaksanakan prosedur identifikasi sebab- } \\
\text { sebab dan jenis-jenis kerusakan pada bodi kendaraan. }\end{array}$ \\
\hline & & $\begin{array}{l}\text { Memiliki pengetahuan dan mampu melaksanakan prosedur perkiraan, } \\
\text { penentuan, dan rekomendasi perbaikan secara tertulis berdasarkan hasil dari } \\
\text { diagnosis pada kerusakan yang terjadi. }\end{array}$ \\
\hline & & $\begin{array}{l}\text { Memiliki pengetahuan dan mampu melaksanakan prosedur manajemen } \\
\text { persediaan dan penentuan harga suku cadang dalam perbaikan. }\end{array}$ \\
\hline & & $\begin{array}{l}\text { Memiliki pengetahuan dan mampu melaksanakan prosedur penentuan harga } \\
\text { akhir untuk pelanggan dalam perbaikan. }\end{array}$ \\
\hline & & $\begin{array}{l}\text { Memiliki pengetahuan dan mampu melaksanakan manajemen pelatihan } \\
\text { kelompok kecil yang meliputi perencanaan, pelaksanaan, dan evaluasi. }\end{array}$ \\
\hline & & $\begin{array}{l}\text { Memiliki pengetahuan dan mampu melaksanakan prosedur manajemen } \\
\text { penilaian meliputi perencanaan penilaian, penentuan metode penilaian, } \\
\text { pengembangan alat penilaian, penyelenggaraan penilaian, pengkajian, dan } \\
\text { pelaporan bukti dari hasil penilaian. }\end{array}$ \\
\hline & & $\begin{array}{l}\text { Memiliki pengetahuan dan mampu melaksanakan prosedur menjaga relasi } \\
\text { bisnis dengan pihak asuransi dan pihak yang terkait lainnya. }\end{array}$ \\
\hline & & $\begin{array}{l}\text { Memiliki pengetahuan dan mampu melaksanakan prosedur penanganan dan } \\
\text { pelayanan pelanggan. }\end{array}$ \\
\hline & & $\begin{array}{l}\text { Memiliki pengetahuan dan mampu melaksanakan prosedur manajemen } \\
\text { keuangan. }\end{array}$ \\
\hline \multirow[t]{8}{*}{8} & \multirow{8}{*}{$\begin{array}{l}\text { Profil Kompetensi } \\
\text { Sistem Lain (Other } \\
\text { System Competencies) }\end{array}$} & $\begin{array}{l}\text { Memiliki pengetahuan dan mampu melaksanakan prosedur pensolderan, } \\
\text { pelepasan, pemasangan, dan perakitan perangkat unit elektronika kendaraan. }\end{array}$ \\
\hline & & $\begin{array}{l}\text { Memiliki pengetahuan dan mampu melaksanakan prosedur perbaikan dan } \\
\text { perawatan sistem air conditioner (AC). }\end{array}$ \\
\hline & & $\begin{array}{l}\text { Memiliki pengetahuan dan mampu melaksanakan prosedur pengetesan, } \\
\text { pengisian, dan penggantian baterai kendaraan. }\end{array}$ \\
\hline & & $\begin{array}{l}\text { Memiliki pengetahuan dan mampu melaksanakan prosedur perbaikan sistem } \\
\text { kemudi, rem, dan suspensi kendaraan. }\end{array}$ \\
\hline & & $\begin{array}{l}\text { Memiliki pengetahuan dan mampu melaksanakan prosedur penyetelan } \\
\text { geometri roda depan kendaraan. }\end{array}$ \\
\hline & & $\begin{array}{l}\text { Memiliki pengetahuan dan mampu melaksanakan prosedur identifikasi dan } \\
\text { perbaikan sistem antilock brake system (ABS). }\end{array}$ \\
\hline & & $\begin{array}{l}\text { Memiliki pengetahuan dan mampu melaksanakan prosedur perbaikan struktur } \\
\text { rangka (chasis) kendaraan. }\end{array}$ \\
\hline & & $\begin{array}{l}\text { Memiliki pengetahuan dan mampu melaksanakan prosedur pembongkaran dan } \\
\text { pemasangan komponen sistem mekanik dan elektronik yang berhubungan } \\
\text { dengan perbaikan bodi kendaraan. }\end{array}$ \\
\hline
\end{tabular}

\section{Profil Kompetensi pada Dokumen KTSP SMK TPBO di Kabupaten Bantul}

Profil kompetensi pada dokumen KTSP SMK TPBO di Kabupaten Bantul memuat Standar Kompetensi (SK) dan Kompetensi Dasar (KD) sesuai dengan Permendiknas Nomor 28 Tahun 2009 yang terdiri dari 22 butir standar kompetensi dan 85 butir kompetensi dasar. Dari 85 butir kompetensi dasar tersebut dilakukan pengelompokan menjadi 6 (enam) profil bidang kompetensi sesuai dengan bidang pekerjaannya. Berdasarkan pengelompokan tersebut, dihasilkan: (1) kompetensi umum terdiri dari 32 butir kompetensi, (2) kompetensi perbaikan panel terdiri dari 25 
butir kompetensi, (3) kompetensi pengecatan panel terdiri dari 13 butir kompetensi, (4) kompetensi perbaikan bodi bukan panel terdiri dari 8 butir kompetensi, (5) kompetensi analisis dan manajemen terdiri dari 4 butir kompetensi, dan (6) kompetensi sistem lain terdiri dari 3 butir kompetensi.

\section{Profil Kompetensi yang diimplementasikan dalam Pembelajaran pada SMK TPBO di Kabupaten Bantul}

Deskripsi profil kompetensi yang diimplementasikan dalam pembelajaran di SMK TPBO di Kabupaten Bantul terbagi dalam 8 (delapan) sub-kompetensi sesuai dengan bidang pekerjaannya. Berikut ini disajikan tabel kompetensi DU/DI hasil penelitian di atas yang diajarkan di SMK TPBO di Kabupaten Bantul.

Tabel 10. Profil Kompetensi Intrapersonal

\begin{tabular}{cccc}
\hline $\begin{array}{c}\text { Kompe- } \\
\text { tensi }\end{array}$ & Hasil & $\begin{array}{c}\text { Kompe- } \\
\text { tensi }\end{array}$ & Hasil \\
\hline Butir 1 & Diajarkan & Butir 15 & Diajarkan \\
Butir 2 & Diajarkan & Butir 16 & Diajarkan \\
Butir 3 & Diajarkan & Butir 17 & Diajarkan \\
Butir 4 & Diajarkan & Butir 18 & Diajarkan \\
Butir 5 & Diajarkan & Butir 19 & Diajarkan \\
Butir 6 & Diajarkan & Butir 20 & Diajarkan \\
Butir 7 & Diajarkan & Butir 21 & Diajarkan \\
Butir 8 & Diajarkan & Butir 22 & Diajarkan \\
Butir 9 & Diajarkan & Butir 23 & Diajarkan \\
Butir 10 & Diajarkan & Butir 24 & Diajarkan \\
Butir 11 & Diajarkan & Butir 25 & Diajarkan \\
Butir 12 & Diajarkan & Butir 26 & Diajarkan \\
Butir 13 & Diajarkan & Butir 27 & Diajarkan \\
Butir 14 & Diajarkan & Butir 28 & Diajarkan \\
\hline
\end{tabular}

Tabel 11. Profil Kompetensi Interpersonal

\begin{tabular}{clll}
\hline $\begin{array}{c}\text { Kompe- } \\
\text { tensi }\end{array}$ & Hasil & $\begin{array}{c}\text { Kompe- } \\
\text { tensi }\end{array}$ & Hasil \\
\hline Butir 1 & Diajarkan & Butir 10 & Diajarkan \\
Butir 2 & Diajarkan & Butir 11 & Diajarkan \\
Butir 3 & Diajarkan & Butir 12 & Diajarkan \\
Butir 4 & Diajarkan & Butir 13 & Diajarkan \\
Butir 5 & Diajarkan & Butir 14 & Diajarkan \\
Butir 6 & Diajarkan & Butir 15 & Diajarkan \\
Butir 7 & Diajarkan & Butir 16 & Diajarkan \\
Butir 8 & Diajarkan & Butir 17 & Diajarkan \\
Butir 9 & Diajarkan & Butir 18 & Diajarkan \\
\hline
\end{tabular}

Tabel 12. Profil Kompetensi Umum

\begin{tabular}{clll}
\hline $\begin{array}{c}\text { Kompe- } \\
\text { tensi }\end{array}$ & Hasil & $\begin{array}{c}\text { Kompe- } \\
\text { tensi }\end{array}$ & Hasil \\
\hline Butir 1 & Diajarkan & Butir 12 & Diajarkan \\
Butir 2 & Diajarkan & Butir 13 & Tidak \\
Butir 3 & Diajarkan & Butir 14 & Tidak \\
Butir 4 & Diajarkan & Butir 15 & Diajarkan \\
Butir 5 & Tidak & Butir 16 & Diajarkan \\
Butir 6 & Diajarkan & Butir 17 & Diajarkan \\
Butir 7 & Diajarkan & Butir 18 & Diajarkan \\
Butir 8 & Diajarkan & Butir 19 & Diajarkan \\
Butir 9 & Diajarkan & Butir 20 & Diajarkan \\
Butir 10 & Diajarkan & Butir 21 & Diajarkan \\
Butir 11 & Diajarkan & Butir 22 & Diajarkan \\
\hline
\end{tabular}

Tabel 13. Profil Kompetensi Perbaikan Panel

\begin{tabular}{llcl}
\hline $\begin{array}{c}\text { Kompe- } \\
\text { tensi }\end{array}$ & \multicolumn{1}{c}{ Hasil } & $\begin{array}{c}\text { Kompe- } \\
\text { tensi }\end{array}$ & \multicolumn{1}{c}{ Hasil } \\
\hline Butir 1 & Diajarkan & Butir 15 & Diajarkan \\
Butir 2 & Tidak & Butir 16 & Diajarkan \\
Butir 3 & Tidak & Butir 17 & Diajarkan \\
Butir 4 & Tidak & Butir 18 & Diajarkan \\
Butir 5 & Diajarkan & Butir 19 & Diajarkan \\
Butir 6 & Tidak & Butir 20 & Tidak \\
Butir 7 & Tidak & Butir 21 & Tidak \\
Butir 8 & Diajarkan & Butir 22 & Diajarkan \\
Butir 9 & Tidak & Butir 23 & Diajarkan \\
Butir 10 & Tidak & Butir 24 & Diajarkan \\
Butir 11 & Diajarkan & Butir 25 & Diajarkan \\
Butir 12 & Tidak & Butir 26 & Diajarkan \\
Butir 13 & Tidak & Butir 27 & Diajarkan \\
Butir 14 & Diajarkan & & \\
\hline
\end{tabular}

Tabel 14. Profil Kompetensi Pengecatan Panel

\begin{tabular}{clcl}
\hline $\begin{array}{c}\text { Kompe- } \\
\text { tensi }\end{array}$ & \multicolumn{1}{c}{ Hasil } & $\begin{array}{c}\text { Kompe- } \\
\text { tensi }\end{array}$ & \multicolumn{1}{c}{ Hasil } \\
\hline Butir 1 & Diajarkan & Butir 11 & Tidak \\
Butir 2 & Tidak & Butir 12 & Diajarkan \\
Butir 3 & Diajarkan & Butir 13 & Diajarkan \\
Butir 4 & Diajarkan & Butir 14 & Tidak \\
Butir 5 & Diajarkan & Butir 15 & Tidak \\
Butir 6 & Diajarkan & Butir 16 & Tidak \\
Butir 7 & Diajarkan & Butir 17 & Tidak \\
Butir 8 & Diajarkan & Butir 18 & Tidak \\
Butir 9 & Tidak & Butir 19 & Diajarkan \\
Butir 10 & Tidak & Butir 20 & Diajarkan \\
\hline
\end{tabular}


Tabel 15. Profil Kompetensi Perbaikan Bodi Bukan Panel

\begin{tabular}{clll}
\hline $\begin{array}{c}\text { Kompe- } \\
\text { tensi }\end{array}$ & \multicolumn{1}{c}{ Hasil } & $\begin{array}{c}\text { Kompe- } \\
\text { tensi }\end{array}$ & Hasil \\
\hline Butir 1 & Diajarkan & Butir 7 & Tidak \\
Butir 2 & Diajarkan & Butir 8 & Tidak \\
Butir 3 & Tidak & Butir 9 & Tidak \\
Butir 4 & Tidak & Butir 10 & Tidak \\
Butir 5 & Diajarkan & Butir 11 & Tidak \\
Butir 6 & Tidak & Butir 12 & Tidak \\
\hline
\end{tabular}

Tabel 16. Profil Kompetensi Analisis dan Manajemen

\begin{tabular}{clll}
\hline $\begin{array}{c}\text { Kompe- } \\
\text { tensi }\end{array}$ & \multicolumn{1}{c}{ Hasil } & $\begin{array}{c}\text { Kompe- } \\
\text { tensi }\end{array}$ & \multicolumn{1}{c}{ Hasil } \\
\hline Butir 1 & Diajarkan & Butir 7 & Diajarkan \\
Butir 2 & Diajarkan & Butir 8 & Diajarkan \\
Butir 3 & Diajarkan & Butir 9 & Tidak \\
Butir 4 & Diajarkan & Butir 10 & Tidak \\
Butir 5 & Tidak & Butir 11 & Tidak \\
Butir 6 & Diajarkan & Butir 12 & Tidak \\
\hline
\end{tabular}

Tabel 17. Profil Kompetensi Sistem Lain

\begin{tabular}{clcl}
\hline $\begin{array}{c}\text { Kompe- } \\
\text { tensi }\end{array}$ & \multicolumn{1}{c}{ Hasil } & $\begin{array}{c}\text { Kompe- } \\
\text { tensi }\end{array}$ & Hasil \\
\hline Butir 1 & Tidak & Butir 5 & Tidak \\
Butir 2 & Tidak & Butir 6 & Tidak \\
Butir 3 & Diajarkan & Butir 7 & Tidak \\
Butir 4 & Tidak & Butir 8 & Tidak \\
\hline
\end{tabular}

Tingkat Relevansi antara Profil Kompetensi DU/DI Bidang Perbaikan Bodi Otomotif dengan Profil Kompetensi pada Dokumen KTSP SMK TPBO di Kabupaten Bantul

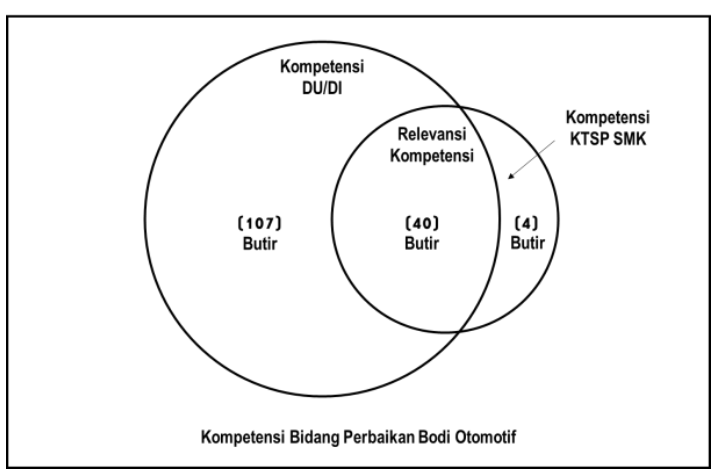

Gambar 1. Peta Kompetensi antara KTSP SMK TPBO vs DU/DI.

Berdasarkan profil kompetensi DU/DI bidang perbaikan bodi otomotif dan profil kompetensi pada dokumen KTSP SMK TPBO di Kabupaten Bantul hasil penelitian tersebut, maka klasifikasi peta kompetensi dari kedua profil kompetensi tersebut disajikan pada Gambar 1.

Berdasarkan Gambar 1, maka dapat disimpulkan bahwa secara keseluruhan tingkat relevansi antara daftar kompetensi pada dokumen KTSP SMK N 1 Sanden dan SMK Teknologi Bantul dengan daftar kompetensi DU/DI bidang perbaikan bodi otomotif adalah $40 / 147 \times 100 \%=27,211 \%$ atau dapat dikatakan tidak relevan.

Tingkat Relevansi antara Profil Kompetensi DU/DI Bidang Perbaikan Bodi Otomotif dengan Profil Kompetensi yang diimplementasikan dalam Pembelajaran pada SMK TPBO di Kabupaten Bantul

Berdasarkan profil kompetensi DU/DI bidang perbaikan bodi otomotif dan profil kompetensi yang diimplementasikan dalam pembelajaran di SMK TPBO di Kabupaten Bantul hasil penelitian di atas, maka klasifikasi peta kompetensi dari kedua profil kompetensi tersebut dapat dilihat pada Gambar 2.

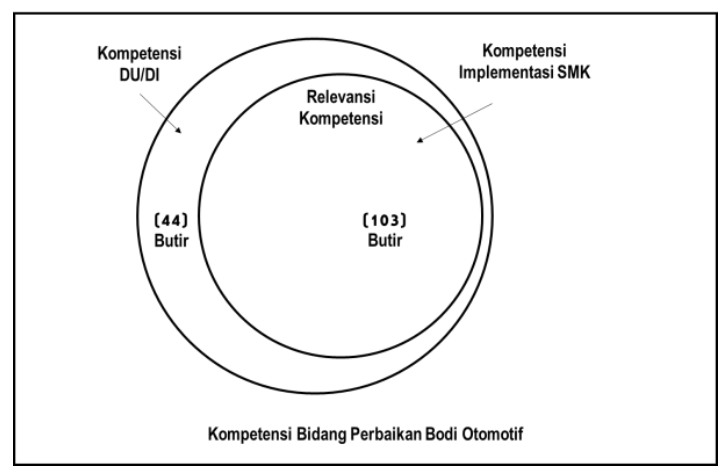

Gambar 2. Peta Kompetensi antara Implementasi pada SMK TPBO vs DU/DI.

Berdasarkan Gambar 2, maka dapat disimpulkan bahwa secara keseluruhan tingkat relevansi antara daftar kompetensi yang diimplementasikan dalam pemebelajaran pada SMK N 1 Sanden dan SMK Teknologi Bantul dengan daftar kompetensi yang menjadi kebutuhan DU/DI adalah 103/147 x 100\% = $70,068 \%$ atau dapat dikatakan relevan.

\section{Pembahasan}

Profil kompetensi DU/DI bidang perbaikan bodi otomotif

ASEAN Economic Community (AEC) yang mulai diterapkan pada tahun 2015, salah 
satu karakteristiknya adalah adanya aliran bebas tenaga kerja terdidik. Dengan adanya aliran bebas tenaga kerja terdidik di kawasan ASEAN ini, menuntut setiap orang memiliki kompetensi yang cukup memadai untuk dapat bersaing dengan yang lainnya. Kompetensi yang harus dikuasai merupakan kompetensi yang menjadi kebutuhan DU/DI. Oleh karena itu, sangat penting mengetahui dan mengidentifikasi kompetensi yang menjadi kebutuhan DU/DI.

Selain 147 butir kompetensi yang menjadi kebutuhan DU/DI di atas, berdasarkan data pendukung melalui wawancara menunjukkan bahwa terdapat 2 (dua) tambahan kompetensi bidang perbaikan bodi otomotif yang dibutuhkan DU/DI. Kedua kompetensi tersebut adalah (1) memiliki kemampuan atau sifat untuk melakukan perubahan secara terusmenerus (continously improvement) dan (2) memiliki kemampuan membaca dan memahami TDS (Technical Data Sheet) dari material pengecatan yang akan digunakan. Oleh karena itu, apabila ditambahkan dengan dua kompetensi tambahan tersebut, maka jumlah butir kompetensi bidang perbaikan bodi otomotif yang menjadi kebutuhan DU/DI menjadi 149 butir kompetensi.

SMK sebagai salah satu lembaga pendidikan kejuruan memiliki kewajiban untuk memberikan bekal kompetensi kepada peserta didik yang sesuai dengan kebutuhan DU/DI. 149 butir kompetensi yang terbagi dalam 8 ranah kompetensi DU/DI bidang perbaikan bodi otomotif harus menjadi dasar dalam pengembangan kurikulum SMK sehingga diharapkan lulusan SMK mampu bersaing dalam dunia kerja.

\section{Profil Kompetensi pada SMK TPBO di Kabupaten Bantul}

SMK sebagai salah satu lembaga pendidikan kejuruan memiliki kewajiban untuk menyelenggarakan pendidikan dalam rangka memberi bekal kompetensi kepada peserta didik agar siap dalam memasuki dunia kerja. Kesiapan peserta didik dalam memasuki dunia kerja salah satunya ditentukan oleh kompetensi yang dimiliki oleh peserta didik tersebut. Kompetensi yang dimiliki peserta didik tersebut harus sesuai dengan kompetensi yang menjadi kebutuhan dunia kerja. Oleh karena itu, kurikulum SMK sebagai suatu perangkat penyelenggaraan proses pembel- ajaran di SMK harus mengakomodasi kompetensi-kompetensi yang menjadi kebutuhan dunia kerja atau DU/DI.

Kajian dari hasil penelitian lainnya menunjukkan bahwa terdapat 5 butir kompetensi tambahan yang diimplementasikan di SMK N 1 Sanden dan SMK Teknologi Bantul yang tidak terdapat dalam daftar kompetensi kerja dalam instrumen yang digunakan. Hal ini terungkap melalui kajian dokumen dan data wawancara yang dilakukan. kelima butir kompetensi tersebut terdiri dari 4 butir kompetensi ranah umum dan 1 butir kompetensi ranah perbaikan panel. 5 butir kompetensi tambahan tersebut adalah: (1) memahami proses-proses dasar pembentukan logam yaitu proses pembentukan dan proses pengecoran; (2) menjelaskan proses-proses mesin konversi energi yaitu konsep motor bakar, motor listrik, generator listrik, dan konsep refrigerasi; (3) menggunakan fastener; (4) memahami dasardasar mesin yaitu dasar ilmu statika dan tegangan, elemen mesin, dan material kemampuan proses; dan (5) memiliki kompetensi atau kemampuan dalam melakukan perbaikan panel bodi dengan vacuum cup.

Selain terdapat tambahan kompetensi yang diajarkan yang tidak terdapat dalam daftar kompetensi kerja dalam instrumen yang digunakan, kajian dari hasil penelitian menunjukkan bahwa terdapat 18 butir kompetensi yang terdapat dalam dokumen kurikulum yang tidak diimplementasikan pada pembelajaran di SMK TPBO di Kabupaten Bantul. 18 butir kompetensi tersebut adalah: (1) melaksanakan pemanasan termal; (2) melaksanakan pemotongan termal; (3) melaksanakan pengelasan las $\mathrm{CO}_{2}(\mathrm{MIG})$; (4) Melaksanakan pengelasan las titik; (5) melaksanakan pengetokan panel dengan cara hot dan cold shrinking; (6) menguji penyesuaian warna dengan kartu warna; (7) memperbaiki luka kecil, retak dan goresan pada kaca yang berlapis; (8) mengidentifikasi kaca film; (9) mempersiapkan permukaan kaca; (10) memasang kaca film; (11) melepas pelindung moulding, transfer dan decal; (12) memperbaiki pelindung moulding, transfer dan decal; (13) menentukan prosedur perbaikan dan penggantian secara tertulis; (14) menjelaskan dasar kelistrikan bodi; (15) membongkar kelistrikan bodi; (16) memasang kelistrikan bodi; (17) melepas perangkat tambahan elektronik; dan (18) memasang perangkat 
tambahan. Data tersebut memberikan gambaran bahwa implementasi terhadap dokumen kurikulum KTSP SMK TPBO di Kabupaten Bantul masih sangat lemah.

\section{Tingkat Relevansi antara Profil Kompetensi DU/DI Bidang Perbaikan Bodi Otomotif dengan Profil Kompetensi pada SMK TPBO di Kabupaten Bantul}

Data kajian hasil penelitian yang telah diuraikan tersebut, memberikan gambaran bahwa kontribusi kompetensi yang ada di dalam dokumen KTSP SMK TPBO di Kabupaten Bantul tersebut belum mampu menjawab kebutuhan DU/DI dalam hal kompetensi bidang perbaikan bodi otomotif yaitu hanya 27,211\% (40 butir kompetensi dari 147 butir kompetensi yang menjadi kebutuhan DU/DI). Hal ini sangat penting untuk diperhatikan dalam rangka mewujudkan penyelenggaraan SMK yang efektif. Pengembangan kurikulum merupakan hal yang sangat penting untuk dilakukan agar apa yang diajarkan di SMK TPBO sesuai dengan kebutuhan DU/DI dan lulusan SMK tersebut memiliki daya saing yang tinggi khususnya dalam rangka menghadapi persaingan di era ASEAN Economic Community (AEC) ini.

Data kajian hasil penelitian yang telah diuraikan tersebut, memberikan gambaran bahwa kontribusi pembelajaran kompetensi pada SMK TPBO di Kabupaten Bantul belum mampu sesuai dengan kebutuhan DU/DI terutama dalam ranah kompetensi profesional keteknikan. Hal ini ditunjukkan dengan hanya sebesar 56,436\% kompetensi profesional keteknikan yang diimplementasikan di SMK TPBO dari semua kompetensi profesional keteknikan bidang perbaikan bodi otomotif yang menjadi kebutuhan DU/DI. Fenomena tersebut sangat penting untuk diperhatikan dalam rangka mewujudkan efektivitas penyelenggaraan SMK sebagai salah satu lembaga pendidikan kejuruan yang mampu memenuhi kebutuhan DU/DI dan memiliki daya saing yang tinggi khususnya dalam rangka menghadapi persaingan di era ASEAN Economic Community (AEC) ini.

\section{SIMPULAN DAN SARAN}

\section{Simpulan}

Profil kompetensi DU/DI bidang perbaikan bodi otomotif terdiri atas 147 butir kompetensi yang terbagi dalam 8 ranah kompetensi berdasarkan bidang pekerajaan yaitu: (1) kompetensi intrapersonal terdiri dari 28 butir kompetensi, (2) kompetensi interpersonal terdiri dari 18 butir kompetensi, (3) kompetensi umum terdiri dari 22 butir kompetensi, (4) kompetensi perbaikan panel terdiri dari 27 butir kompetensi, (5) kompetensi pengecatan panel terdiri dari 20 butir kompetensi, (6) kompetensi perbaikan bodi bukan panel terdiri dari 12 butir kompetensi, (7) kompetensi analisis dan manajemen terdiri dari 12 butir kompetensi, dan (8) kompetensi sistem lain terdiri dari 8 butir kompetensi.

Profil kompetensi pada SMK TPBO di Kabupaten Bantul terbagi dalam 2 hal yaitu sebagai berikut. Pertama, profil kompetensi yang ada dalam dokumen kurikulum KTSP SMK TPBO di Kabupaten Bantul terdiri atas 85 butir kompetensi yang terbagi dalam 6 ranah kompetensi berdasarkan bidang pekerajaan yaitu: (1) kompetensi umum terdiri dari 32 butir kompetensi, (2) kompetensi perbaikan panel terdiri dari 25 butir kompetensi, (3) kompetensi pengecatan panel terdiri dari 13 butir kompetensi, (4) kompetensi perbaikan bodi bukan panel terdiri dari 8 butir kompetensi, (5) kompetensi analisis dan manajemen terdiri dari 4 butir kompetensi, dan (6) kompetensi sistem lain terdiri dari 3 butir kompetensi. Kedua, profil kompetensi kerja yang diimplementasikan dalam pembelajaran pada SMK TPBO di Kabupaten Bantul terdiri atas 103 butir kompetensi yang terbagi dalam 8 ranah kompetensi berdasarkan bidang pekerajaan yaitu: (1) kompetensi intrapersonal terdiri dari 28 butir kompetensi, (2) kompetensi interpersonal terdiri dari 18 butir kompetensi, (3) kompetensi umum terdiri dari 19 butir kompetensi, (4) kompetensi perbaikan panel terdiri dari 16 butir kompetensi, (5) kompetensi pengecatan panel terdiri dari 11 butir kompetensi, (6) kompetensi perbaikan bodi bukan panel terdiri dari 3 butir kompetensi, (7) kompetensi analisis dan manajemen terdiri dari 7 butir kompetensi, dan (8) kompetensi sistem lain terdiri dari 1 butir kompetensi.

Tingkat relevansi kompetensi antara SMK dan DU/DI terbagi menjadi 2 (dua) bagian yaitu sebagai berikut. Pertama, Tingkat relevansi kompetensi antara profil kompetensi dalam dokumen kurikulum KTSP SMK TPBO di Kabupaten Bantul dan profil 
kompetensi DU/DI bidang perbaikan bodi otomotif menunjukkan angka $27,211 \%$ atau dapat dikatakan tidak relevan. Kedua, tingkat relevansi kompetensi antara profil kompetensi yang diimplementasikan dalam pembelajaran pada SMK TPBO di Kabupaten Bantul dan profil kompetensi DU/DI bidang perbaikan bodi otomotif menunjukkan angka 70,068\% atau dapat dikatakan relevan.

\section{Saran}

Kompetensi dalam dokumen kurikulum KTSP SMK TPBO berdasarkan hasil penelitian dinyatakan tidak relevan terhadap kebutuhan DU/DI yaitu hanya $27,211 \%$ sehingga perlu diterapkan kurikulum 2013 dengan kompetensi DU/DI bidang perbaikan bodi otomotif berdasarkan hasil dari penelitian ini sebagai dasar dalam pengembangan kurikulumnya.

\section{DAFTAR PUSTAKA}

Ali, M. (2009). Pendidikan untuk pembangunan nasional. Bandung: PT Imperial Bhakti Utama.

ASEAN. (2008). ASEAN economic community blueprint. Jakarta: ASEAN Sekretariat.

Azwar, S. (2015). Skala psikologi. Yogyakarta: Pustaka Pelajar.

Direktorat Pembinaan SMK. (2014). Data pokok SMK. Diambil pada tanggal 19 Mei 2015 dari http://datapokok.ditpsmk.net/.

Glass, G. V. \& Hopkins, K. D. (1996). Statistical methods in education and psychology. United State of America: Allyn \& Bacon.

Isjoni. (2008). Memajukan bangsa dengan pendidikan. Yogayakarta: Pustaka Pelajar.

Jatmoko, D. (2013). Relevansi kurikulum SMK kompetensi keahlian teknik kendaraan ringan terhadap kebutuhab dunia industri di kabupaten sleman. Jurnal Pendidikan Vokasi, 3 (1). Retrieved from http://journal.uny.ac.id/index.php/jpv/ar $\underline{\text { ticle/view/1572 }}$

Kementerian Ketenagakerjaan Republik Indonesia. (2014). Penganggur terbuka menurut keterampilan dan kategori. Diambil pada tanggal 19 Mei 2015 dari http://pusdatinaker.balitfo.depnakertran s.go.id/kuprovinsi/prop62E5rptsmry.ph p?pageno $=1 \&$ grpperpage $=\mathrm{ALL}$

Palmieri, P. (2004). The Australian Flexible Learning Framework. Dalam Louise Moran \& Greville Rumble. (Eds). Vocational education and training through open and distance learning (pp.84-98). London: Routledge Falmer.

Priyatama, A., \& Sukardi, S. (2013). Profil kompetensi siswa SMK kompetensi keahlian teknik kendaraan ringan di kota pekalongan. Jurnal Pendidikan Vokasi, 3(2). Retrieved from http://journal.uny.ac.id/index.php/jpv/ar $\underline{\text { ticle/view/1593 }}$

Prosser, C.A. \& Quigley, T.H. (1950). Vocational education in a democracy. Great Britain: American Technical Society.

Simamora, I. G. (2009). Relevansi kompetensi siswa SMK Negeri program keahlian teknik mekanik otomotif dengan kebutuhan dunia usaha/dunia industri otomotif di Kota Medan. Tesis magister, tidak diterbitkan. Universitas Sumatera Utara.

Sudira, P. (2012). Filosofi dan teori pendidikan vokasi dan kejuruan. Yogyakarta: UNY Press.

United Nations Development Programme. (2014). Human Development Report 2014. New York: United Nations Development Programme.

Wagiran. (2013). Metodologi penelitian pendidikan (teori dan implementasi). Yogyakarta: Deepublish.

Wangke, H. (2014). Peluang indonesia dalam masyarakat ekonomi ASEAN 2015. Jakarta: Pusat Pengkajian, Pengolahan Data, dan Informasi (P3DI) Setjen DPR RI. 